\title{
Institutional Innovations in China: Can China Serve as an Alternative Development Model
}

\begin{abstract}
Naila Tasneem
Urban Sector Planning \& Management Services Unit (Pvt) Limited, Government of the Punjab, Lahore, Pakistan

Over the past few decades, China has emerged as an alternative model of development especially for countries in Asia and Africa. Not only has China achieved impressive growth rates, lifted almost half a billion people out of poverty but has also emerged as a rising global power. Many economists and development practitioners look towards Western democracies as a model of growth and development. However, due to China's silent rise as a major global economic power, many countries particularly in Asia and Africa are relating to China's institutional reforms and development. These include reforms towards greater decentralization, formation of special economic zones, promotion of private entrepreneurship, and other experimentations. This paper looks at these institutional innovations in light of their relevance for other developing countries. The analysis in this paper elucidates why China can serve as an alternative model of development despite some imperfections. The unorthodox, innovative, and experimental solutions provided by the Chinese experience show that governments in developing countries should be open to creative ways of problem solving rather than rigid technocratic approaches.
\end{abstract}

Keywords: China, institutions, economic development, economic growth

The world economy in the past few decades has evolved with emergence of new players. Interestingly, China has taken a center stage due to its dynamic, innovative approaches that have led to remarkable economic progress. China maintained a high economic growth rate for nearly three decades, since the beginning of its economic reform in 1978. The average GDP (Gross Domestic Product) growth rate during the period of 1979-2000 was $9.2 \%$, and further accelerated to $10.1 \%$ from 2001 to 2006 . This progress has led many developing countries to view Chinese experience as a model for development in absence of property rights and effective governance. Many developing countries in South Asia and Sub-Saharan Africa despite their grave problems would like to emulate Chinese growth experience. Many of these economies are trying to make a successful transition into a more democratic, responsive, and effective governance structure. However, they need to address issues like poverty, hunger, and illiteracy along with sustainable economic development. The experimental, gradualist approaches adopted by Chinese government seem to provide more pragmatic and innovative solutions to governments in developing countries. Promoting decentralized governance at local levels, private entrepreneurship, and women empowerment are desirable policy choices that can potentially lead to enormous economic development.

Corresponding author: Naila Tasneem, MA in Economics, University of Wisconsin-Milwaukee, USA, Senior Research Analyst (Development Economics), Punjab Spatial Strategy, Urban Sector Planning \& Management Services Unit (Pvt) Limited, Government of the Punjab, Lahore, Pakistan; research fields: development economics, public policy, governance, institutional economics, urban economics, fiscal federalism. 
Therefore, we begin this study by providing a brief literature review on China's institutional innovation policies and then we briefly discuss institutional innovations in China like decentralization, Township and Village Enterprises (TVEs). Then we build a model on innovative policies and through simple OLS (Ordinary Least Squares) regression try to assess their impact on economic growth and exports. In the end, we present the results and conclusions based on our findings.

\section{Literature Review}

After initiating market reforms in 1978, China has evolved from a centrally planned to a market based economy and experienced robust economic and social development. Its GDP growth averaging about $10 \%$ a year has lifted more than 500 million people out of poverty. With a population of 1.3 billion, China recently became the second largest economy and is increasingly playing an important and influential role in the global economy according to World Bank (2015). Investment-led growth has been one of the defining features of China's growth. China's sustained economic growth and increased competitiveness in manufacturing have been underpinned by massive development of physical infrastructure. Role of infrastructure has been emphasized in various studies (World Bank, 1994; Calderón \& Servén, 2004; Estache, 2008). Infrastructural development both social and economic is one of the major determinants of growth, particularly in developing countries. The experience from China suggests that it is necessary to design an economic policy that improves physical infrastructure as well as human capital formation for sustainable economic growth in developing countries according to Sahoo, Dash, and Nataraj (2010). Zhu (2012) on the other hand argued that the rapid growth of the last three decades has been driven by productivity growth which has been induced by reducing distortions and improving economic incentives.

However, North (1990) and Lin and Nugent (1995) emphasized the role of institutions in explanation of economic development as well as of the differential performance of economies through time. Hence, Kozul-Wright and Rayment (1997) considered Chinese experience as very instructive for the analysis of the institutional dynamics of any transitional economy.

Further, Dulbecco and Renard (2003) demonstrated that decentralization was the main institutional vector of Chinese economic reforms. On the other hand, Byrd and Lin (1990) pointed out that TVEs served as a major stepping-stone in changing China's institutions. A typical TVE is a collectively owned enterprise located in a township/village. All the people in the township/village that sets up the TVE own the firm collectively. The community government of the township/village "represents" the communal collective owners and is the de facto executive owner of the TVE. Weitzman and Xu (1994) discussed that another major feature of the TVEs is the prevailing of the informal institutions, such as implicit contractual relationships between community governments and TVEs, between TVE employees, and between TVEs. Bardhan and Mookherjee (2006) further elucidated that major reforms were initiated and carried out by Chinese subnational governments since they had incentives and resources to proceed and this is why China is the only country where the local governments have played a leading role in increasing rates of growth. According to Zeng (2011) and Yeung, Lee, and Kee (2009), Special Economic Zones (SEZs) accelerated the pace of China's economic revitalization due to factors like strategic location advantages, FDI (Foreign Direct Investment), preferential policies, and institutional autonomy.

Schellekens (2013) pointed out that China's transformation over the past three decades into a global economic powerhouse wielded increasing influence over the development path of other countries, either 
directly through bilateral trade and financial flows or indirectly through growth spillovers and terms of trade effects.

In another study, McKibbin and Huang (1996) used a dynamic general equilibrium model called the G-CUBED model for the time period (1990 to 2020) to explore possible future paths of the Chinese economy based on projections of population growth, sectoral productivity growth, energy efficiency, and technical change in the Chinese economy. Their findings suggest that strong growth in China is beneficial for the world economy directly through raising world incomes.

\section{China's Rise and the Global Economy}

China's economy in the past few decades has shown a remarkable performance. It has not only shown impressive growth performance but has lifted millions of people out of poverty. According to the IMF, China produced 17\% of the world GDP in 2014 exceeding USA's GDP of world's 16\%. From 1978 to 2009, the average ratios of private consumption, fixed capital formation, and net export to China's GDP were $46 \%, 33 \%$, and $2 \%$ respectively. From 2000 to 2009, the above ratios changed to $40 \%, 39 \%$, and 5\% respectively, which demonstrated that China's economic growth relied more heavily on investment and export in 2000s compared with 1980s and 1990s. China's economic growth performance over the last 30 years has surprised development economists who believed that China will remain in the low/middle income group of nations permanently due to its very large population approximately $1.2+$ billion in 2015. On the other hand, China's performance has also inspired other low and middle income countries to emulate China's approach and achieve higher growth and economic progress. The government in China is also seeking to transform it from a country best known for its low-cost manufacturing to one respected for its innovative capacity. The most important asset for China is human intellectual capital. In the coming 10 to 20 years, the government is keen to transform it to an innovation-driven growth model. China has already emerged as a preferred destination for R\&D investment, both foreign and domestic. China also looks forward to increasing national spending on R\&D from $1.4 \%$ of GDP in 2005 to $2.5 \%$ by $2020^{1}$. Figure 1 shows the increase in China's exports in goods and services through 1978 to 2014 . There has also been a remarkably high rise in the world exports during the same time.

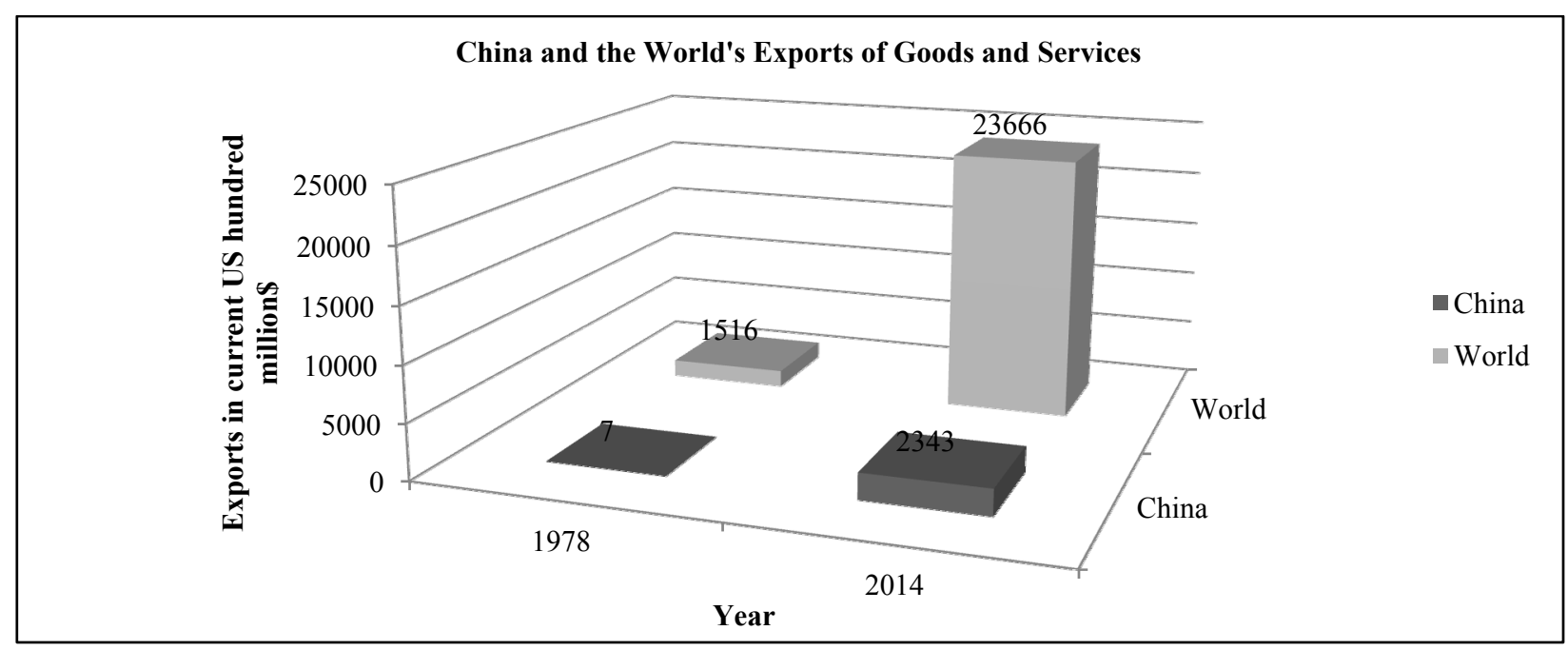

Figure 1. World development indicators 2014.

${ }^{1}$ See: http://www.weforum.org/news/china-global-player. 


\section{BRICS and the World GDP per Capita}

The world we live in today is evolving fast and China's rise confirms that it is also becoming multi-polar. Over the last decade or so, the emergence of developing countries, and in particular the BRICS (Brazil, Russian Federation, India, China, and South Africa), has provided significant impetus to world economic growth. The progress is expected to continue provided the global environment remains supportive such as openness to cross-border trade, investment, and the lowering of total supply chain costs due to improvements in logistics and advances in information and communications technologies (ICTs). More convergence is happening and developing countries in Sub-Saharan Africa and South Asia are growing fast. The BRICS economy rose from $11 \%$ of global GDP in 1990 to $25 \%$ in 2011 . The rise of BRICS is being described as "great transformation". Financial markets in the BRICS community have expanded in a rapid manner simultaneously with economic growth. Between 1990 and 2010, market capitalization of Brazil rose from a very low of about 4\% of GDP to $74 \%$, India from $12 \%$ to $93 \%$, Russia and China from almost nothing to $70 \%$ and $81 \%$, respectively. In South Africa, it has more than doubled from $123 \%$ to $278 \%{ }^{2}$. Figure 2 below shows the trends in GDP per capita of the BRICS economy over the past two decades. We see that Russia and Brazil surpassed world GDP per capita in 2014 whereas other three economies remained below. Overall, there has been a steady increase in their GDP per capita over the years indicating an improvement in individual living standards across BRICS.

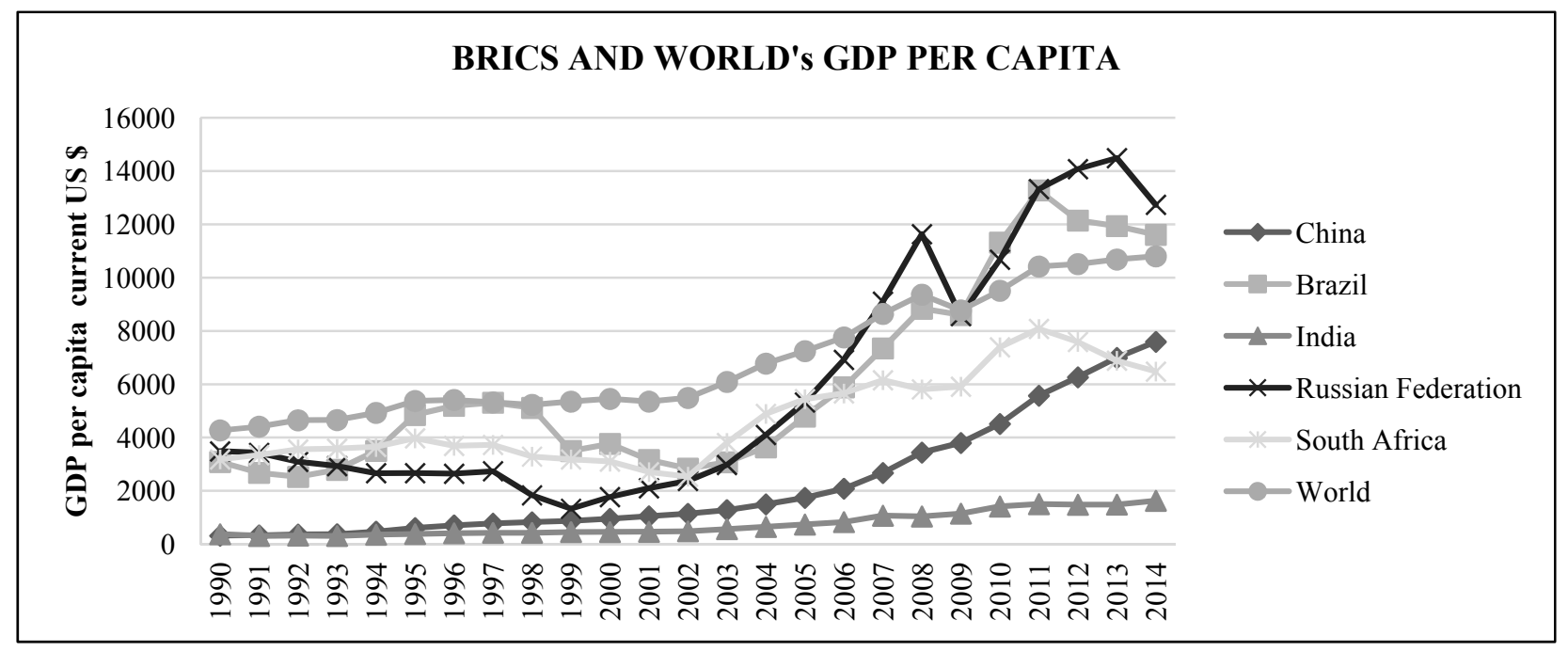

Figure 2. World development indicators 2015.

\section{Institutional Innovations in China}

Chinese government has been undertaking many innovative and heterodox policies that have supported economic development and poverty alleviation. Although China has a highly centralized political government, it has decentralized many aspects of economic governance. Strengthening local development through local governments has been a hallmark of Chinese reforms. Local service delivery is more efficient in China then in many federal states. Hence, Chinese experience has a lot to offer to developing countries trying to make a transition towards decentralization. Promotion of entrepreneurship and private enterprises through credit provision has also boosted economic growth. Below we briefly discuss different innovative policies related to

${ }^{2}$ See: http://www.brics5.co.za/assets/BRICS-and-the-Global-Economy.pdf. 
governance, exports, decentralization, and social and economic progress. Later we build a model to understand the impact of selected social and economic indicator on economic development.

\section{Decentralization}

The Chinese government consists of a region-based multi-level hierarchy. Besides the central government, there are four levels of subnational governments: provincial level, municipal level (or prefecture level), county level, and township level. Although, constitutionally China is not a federal state, in many crucial economic issues, Chinese subnational governments are more powerful than their counterparts in federal countries around the world. Regional governments are major players to the bulk of the Chinese economy. Chinese subnational governments are responsible for much broader regional matters than just fiscal issues (Xu, 2011). Under the supervision of the central government, they initiate, negotiate, implement, divert, and resist reforms, policies, rules, and laws (Xu, 2006).

If we look at China's fiscal decentralization in contrast with its counterparts in the rest of the world during the early 2000s, the total expenditure of Chinese subnational governments accounted for about $70 \%$ of the national total, which was far larger than that of the world's largest federal countries such as the USA (46\%), Germany (40\%), and Russia (38\%) (Wong, 2006).

Lin and Liu (2000) by using provincial data from 1970 to 1993 found that fiscal decentralization has made a positive contribution to the growth process. They also discuss that along with fiscal decentralization, land reform, the non-state sector, and capital accumulation are the key driving forces of China's growth over the reform years. Jin, Qian and Weingast (2005) suggested that fiscal decentralization reforms considerably strengthened the fiscal incentives of provincial governments which are generally conducive to provincial economic development and reform.

\section{Township Village Enterprises (TVEs)}

The most important non-state sector until the mid-1990s was the TVE. By the early 1990s, TVEs accounted for about $4 / 5$ of the output of the non-state sector. Between 1981 and 1990, the total industrial output of TVEs grew at an average annual rate of $28.1 \%$, while the rate for the state sector was $7.7 \%$. As a comparison, China's average annual GDP growth rate was $8.7 \%$ between 1979 and 1991. Moreover, TVEs had substantially higher TFP (Total Factor Productivity) growth rates than the state sector in those years (Xu, 1995).

A typical TVE is a collectively-owned enterprise located in a township/village. All the people in the township/village which "sets up" the TVE own the firm collectively. The community government of the township/village "represents" the communal collective owners, and is the de facto executive owner of the TVE (Byrd \& Lin, 1990).

Although TVEs have declined, the institutional legacy of TVEs in China's economic development and corporate governance remains. Important mechanisms that existed in TVEs, e.g. the intimate involvement of community governments in business and informal institutional arrangements, and their impacts on the rise of entrepreneurship in China are far-reaching (such as on the fast growth of clusters of large number of small private firms in coastal provinces) (Xu, 2011).

The Chinese regional decentralization provided suitable conditions for the growth of non-state firms (Qian $\& \mathrm{Xu}, 1993)$. To a large extent, it is due to the fast development of the TVE sector, China's remarkable economic growth occurred in the first 15 years of reforms despite the lack of secure property rights (Weitzman $\& \mathrm{Xu}, 1994 ; \mathrm{Li}, 1996)$ 
Many developing countries in South Asia and Sub-Saharan Africa aspire for a more democratic and participatory form of governance. Chinese decentralization experience can provide key insights to these countries to improve quality of governance and service delivery at local level. Although China is not a federal state but its effective multi-layered governance has successfully catered to local development and progress. Therefore federations in South Asia (like Pakistan) and Sub-Saharan Africa (like Somalia, South Sudan) can make local governments efficient to boost local economic development and peace building efforts. Developing countries can certainly benefit from China's decentralization experience by understanding China's reform process and formulating policies keeping view of their individual trajectories and resources.

\section{Special Economic Zones (SEZs) in China}

SEZs are considered to be one of China's important institutional innovations that have contributed towards regional development and attracting investment. SEZs are basically "special areas" delimited by a country where, through exemption of customs duty, they formulate various preferential conditions ${ }^{3}$ (Wang, 2013) and provide public facilities in order to attract foreign investors to set up factories whose finished products are mainly for export.

Many studies have discussed the positive impact these SEZs have had on boosting exports, attracting FDI, and promoting regional development. In a comprehensive study on economic impact of SEZs, Wang (2013) made three predictions. Firstly, SEZs increased per capita foreign direct investment by $58 \%$, mainly in the form of foreign-invested and export-oriented industrial enterprises. Secondly, SEZs do not crowd out domestic investment and domestically owned capital stock. Thirdly, they increased TFP growth rate by $0.6 \%$. This study ranging over the time period 1978-2007 suggests that creating SEZs not only brings capital, but also more advanced technology, and provide important policy implications for many developing countries (Wang, 2013).

In a quarter of a century, China has become one of the largest FDI recipient countries in the world, with the world's largest foreign reserves, and also one of the largest trading countries in the world. Another study of $\mathrm{Xu}$ (2011) showed that FDI in China and Chinese exports are essentially driven by the SEZs. The number of SEZs grew from four in 1980 to 342 in 2005. In the beginning when China opened up, 37\% of FDI was located in SEZs in 1985, and 89\% of the national exports came from the SEZs in 1985. However, in 2005, when China became the largest FDI recipient country in the world, 93\% of FDI was located in SEZs, and 93\% of China's exports came from the SEZs. The study suggests that among all the Chinese reform measures, the SEZ has had the greatest direct impact on the global economy (Xu, 2011).

Therefore, developing countries looking towards replicating Chinese progress to attract FDI and boost exports can provide similar incentives and concessions in special zones. Instead of dealing with the bulk of economy all at once, SEZs can prove to be a great starting point for regional collaboration, connectivity, and exports promotion.

\section{Social and Economic Progress (Comparison With Developing Countries in South Asia and Sub-Saharan} Africa)

Table 1 below gives a comparison of selected indicators of some South Asia countries (Pakistan, Sri Lanka, and Bangladesh) and Sub-Saharan African countries (Zimbabwe, Liberia, and Mauritania) with China. We see that some of these countries experience higher growth rates and exports comprise of a major part of

\footnotetext{
${ }^{3}$ Including private property rights protection, tax breaks, and land use policy.
} 
their GDP. Thus, Chinese experience can be relevant for these economies to sustain progress in economic growth and exports promotion.

Table 1

Comparison of Selected Social and Economic Indicators

\begin{tabular}{llllllll}
\hline & China & Pakistan & Sri Lanka & Bangladesh & Zimbabwe & Liberia & Mauritania \\
\hline $\begin{array}{l}\text { GDP growth annual \% } \\
\text { GNI per capita, PPP }\end{array}$ & 7.351 & 5.411811 & 7.367421 & 6.116224 & 3.168211 & 9.3292016 .418889 \\
(current international \$) & 13,130 & 5,100 & 10,270 & 3,340 & 1,710 & 820 & 3,700 \\
Consumer price index (2010=100) & 113.2668141 .7023 & 126.7203 & 135.2829 & 108.8425 & NA & 119.5157 \\
Secondary education, duration (years) & 6 & 7 & 8 & 7 & 6 & 6 & 7 \\
Food imports (\% of merchandise imports) & 5.79025111 .73204 & 13.21024 & NA & 15.13923 & NA & 12.04757 \\
Exports of goods and services (\% of GDP) & 22.6111712 .34661 & 22.33066 & 19.75847 & 26.53331 & 25.7635947 .80154 \\
\hline
\end{tabular}

Note. World Development Indicators (2014).

\section{Model for Innovative Policies}

To understand the dynamic innovative policies and their effects, we have tried to assess the impact of certain social and economic parameters on economic development. We have constructed two models. The first one assesses the impact of some social and economic indicators on economic growth (measured by GDP per capita growth). The second one assesses the impact of these indicators on exports (exports of goods and services as $\%$ of GDP). The results of both these models provide us with important insights on certain key policies that have contributed to the performance of the Chinese economy in the recent years.

Methodology and data. We run simple OLS regression to account for the impact of selected social and economic indicators (that reflect Chinese economic policies in the recent years) first on GDP per capita growth and then on exports of goods and services as \% of GDP. Data for both the models have been collected from WDI (World Development Indicators) indicators and the time period chosen in 1992-2012.

Estimated multiple regression model 1:

$$
Y_{i t}=\beta_{1 i t}+\beta_{2 i} X_{2 i}+\beta_{3 i} X_{3 i}+\beta_{4 i} X_{4 i}+\beta_{5 i} X_{5 i}+\beta_{6 i} X_{6 i}+\beta_{7 i} X_{7 i}
$$

Description of variables:

$Y_{i t}=$ Log of GDP per capita growth (annual \%)

$X_{2 i}=$ Final consumption expenditure (annual \% growth)

$X_{3 i}=$ Renewable energy consumption ( $\%$ of total final energy consumption)

$X_{4 i}=$ Prevalence of undernourishment $(\%$ of population)

$X_{5 i}=$ Domestic credit to private sector ( $\%$ of GDP)

$X_{6 i}=$ Labor force female ( $\%$ of total labor force)

$X_{7 i}=$ Industry value added (annual $\%$ growth)

Table 2 below shows the estimation for variance inflation factor (VIF). The mean VIF is 11.28 showing existence of some multicollinearity among the independent variables; however, it is not too high to have adversely affected results of the model.

Below we have the results for multiple regression model in Table 3. We see that all independent variables for this model have highly significant p-values except for the final consumption expenditure (annual \% growth). The R-squared value is quite high at 0.9696 showing that more than $96 \%$ of the variability in the GDP per capita growth is explained by the independent variables in the model. 
Table 2

Test for Multicollinearity

\begin{tabular}{lll}
\hline Variable & VIF & I/VIF \\
\hline Undernourishment & 23.61 & 0.042360 \\
Renewable energy & 20.98 & 0.047664 \\
Labor force female (\% of total labor force) & 12.34 & 0.081048 \\
Industry value added & 5.57 & 0.179441 \\
Domestic credit to private sector (\% of GDP) & 3.87 & 0.258282 \\
Final consumption expenditure (annual \% growth) & 1.33 & 0.754226 \\
Mean VIF =11.28 & & \\
\hline
\end{tabular}

Table 3

Dependent Variable: GDP per Capita Growth (1992-2012)

\begin{tabular}{llll}
\hline Variable & Coefficient & t-statistic & P-value \\
\hline Final consumption expenditure (annual \% growth) & 0.0000329 & 0.01 & 0.991 \\
Renewable energy & -0.0430384 & -6.77 & -4.59 \\
Undernourishment & -0.0288469 & -1.76 & 0.000 \\
Domestic credit to private sector & -0.0023697 & 7.11 & 0.099 \\
Labor force female (\% of total labor force) & 0.4801314 & 19.17 & 0.000 \\
Industry value added & 0.0714435 & -6.15 & 0.000 \\
Constant & -18.09035 & & 0000 \\
\hline
\end{tabular}

Notes. No. of observations $=22 ;$ R-squared $=0.9696$. We have used robust standard errors for the regression.

Correlation matrix for the model:

|lngdp finalconsump reneweng undernrsh domestcredit femlabor IVA

lngdppercapt $\mid 1.0000$

finalconsump $\mid 0.1466$

1.0000

renewableeng -0.1391

0.2484

1.0000

undernourish | 0.3092

0.3783

0.8410

1.0000

domestcredit | -0.2783

$-0.2286$

$-0.6989$

$-0.8451$

1.0000

femlaborforc | -0.1116

0.1409

0.9524

0.7684

$-0.6608$

1.0000

IVA |

0.8348

0.3573

0.3193

0.7236

$-0.5688$

$0.2415 \quad 1.0000$

Summary statistic:

\begin{tabular}{|c|c|c|c|c|}
\hline Variable | & Mean & Std. Dev. & Min & Max \\
\hline lngdppercapt | 22 & 2.224795 & 0.2098303 & 1.900671 & 2.610078 \\
\hline finalconsump $\mid 22$ & 8.725117 & 2.682059 & 3.836323 & 14.27735 \\
\hline renewableeng |22 & 25.8839 & 5.176109 & 18.01648 & 32.73963 \\
\hline undernourish | 22 & 16.92727 & 3.774751 & 11.1 & 24.5 \\
\hline domesticcred $\mid 22$ & 107.8423 & 14.65172 & 84.49545 & 129.9984 \\
\hline femlaborforc $\mid 22$ & 44.35506 & 0.388713 & 43.63855 & 44.709 \\
\hline IVA & 12.26783 & 3.642856 & 8.158125 & 21.14385 \\
\hline
\end{tabular}


Interpretation of the results from the model 1. In Model 1, we have tried to account for the impact of some key social and economic indicators on Chinese economic performance over the recent decades. We use these indicators to understand the kind of social and economic policies Chinese government has been pursuing and how they have impacted the overall economic performance. It is being claimed that China has recently been experiencing a new normal of slower growth and it will be necessary (Zhang, 2011) for the Chinese economy to boost domestic consumption for higher economic growth. We see that in our analysis, final consumption expenditure (annual \% growth) confirms this proposition as it has a positive coefficient although the p-value is insignificant. Recently China has also been making a lot of investments in energy at home and abroad. We see that renewable energy consumption (\% of total final energy consumption) has a negative relationship with economic growth. This can be explained by the fact that renewable energy consumption in China has decreased quite significantly from $1992(33 \%)$ to $2012(18 \%)$. This shows that use of renewable energy can boost economic growth. Therefore, developing countries facing energy constraints can also invest in alternative energy sources and renewing the existing resources. Shortage of energy leads to decrease in industrial output and shrinking exports hence affecting the overall economic performance. Developing countries can become self-sufficient in energy production by innovative solutions like renewable energy consumption and energy mixes. We also see that prevalence of undernourishment leads to a decrease in economic growth. Therefore, Chinese government must invest more towards not only ensuring food security but also protecting children from stunting and wasting by ensuring adequate nourishment from early age. Organizations like FAO (Food and Agriculture Organization), WHO (World Health Organization), and WFP (World Food Programme) are working towards elimination of hunger and food insecurity. Governments in developing country must make sure that people have access to adequate amount of food to meet their nutritional requirements. Prevalence of undernourishment is not only harmful for physical development and growth but also hampers economic growth and raises health expenditure. We see that domestic credit to private sector (\% of GDP) has a negative effect on economic growth. Domestic credit to private sector refers to financial resources provided to the private sector by financial corporations, such as through loans, purchases of nonequity securities, trade credits, and other accounts. This can be explained by the fact that financial resources have increasingly been used in unproductive activities instead of productive activities by the entrepreneurs and hence lead to a decline in economic progress. Some studies identify all kinds of rent seeking, bribes, tax evasion, and corruption from the beginning of the growth of private sector, and some of the entrepreneurs gained huge profit from such unproductive activities (Wu \& Huang, 2006). Therefore, promoting entrepreneurship can boost economic development if resources are employed in productive activities only. On the other hand, we see that female participation in labor force has a positive and highly significant effect on economic growth. Developing countries must consider female participation in labor force as a huge dividend that can help in raising productivity of the labor force. Governments must promote gender parity in wages and support women through day cares and maternity covers. Women empowerment is recently being considered a great asset for higher economic development and many countries like Germany and Japan are actively pursuing policies to support women in corporate sectors and other roles. Industry value added (annual \% growth) shows a positive impact on GDP per capita growth confirming the contribution of China's industrial policies to overall progress.

Estimated multiple regression model 2:

Description of variables:

$$
Y_{i t}=\beta_{1 i t}+\beta_{2 i} X_{2 i}+\beta_{3 i} X_{3 i}+\beta_{4 i} X_{4 i}+\beta_{5 i} X_{5 i}+\beta_{6 i} X_{6 i}
$$


$Y_{i t}=$ Log of exports of goods and services (\% of GDP)

$X_{2 i}=$ Final consumption expenditure (annual \% growth)

$X_{3 i}=$ Renewable energy consumption ( $\%$ of total final energy consumption)

$X_{4 i}=$ Prevalence of undernourishment ( $\%$ of population)

$X_{5 i}=$ Domestic credit to private sector ( $\%$ of GDP)

$X_{6 i}=$ Labor force female ( $\%$ of total labor force)

Table 4

Test for Multicollinearity

\begin{tabular}{lll}
\hline Variable & VIF & I/VIF \\
\hline Undernourishment & 7.21 & 0.138751 \\
Renewable Energy & 16.48 & 0.060673 \\
Labor force female (\% of total labor force) & 12.29 & 0.081385 \\
Domestic credit to private sector (\% of GDP) & 3.68 & 0.271977 \\
Final consumption expenditure (annual \% growth) & 1.33 & 0.754703 \\
Mean VIF $=8.20$ & &
\end{tabular}

Table 4 above shows the estimation for VIF. The mean VIF is 8.20 which is below 10 showing presence of very little multicollinearity.

Regression results are presented in Table 5. We see that all variables in our analysis have highly significant p-values except for domestic credit to private sector. The R-squared for the model is 0.9296 which is quite high showing that more than $92 \%$ of variability in log of exports of goods and services (as \% of GDP) is explained by the independent variables in the model.

Table 5

Dependent Variable Is Log of Exports of Goods and Services (as \% of GDP)

\begin{tabular}{llll}
\hline Variable & Coefficient & t-statistic & P-value \\
\hline Final consumption expenditure (annual \% growth) & -0.0218715 & -3.27 & 0.005 \\
Renewable energy & -0.1235603 & -11.58 & 0.000 \\
Undernourishment & 0.0364441 & 2.71 & 0.015 \\
Domestic credit to private sector & 0.0013361 & 0.56 & 0.583 \\
Labor force female (\% of total labor force) & 0.9318021 & 7.94 & 0.000 \\
Constant & -35.57193 & -7.33 & 0.000 \\
\hline
\end{tabular}

Notes. No. of observations $=22 ;$ R-squared $=0.9296$. We have used robust standard errors for the regression.

Correlation matrix for the model:

\begin{tabular}{|c|c|c|c|c|c|}
\hline |lnexport & finalcon & reneweng & undrnourish & domestcred & laborfem \\
\hline lnexports $\mid \quad 1.0000$ & & & & & \\
\hline finalconsump $\mid-0.4645$ & 1.0000 & & & & \\
\hline renewableeng $\mid-0.8089$ & 0.2484 & 1.0000 & & & \\
\hline undernourish | -0.6276 & 0.3783 & 0.8410 & 1.0000 & & \\
\hline domesticredt | 0.4856 & -0.2286 & -0.6989 & -0.8451 & 1.0000 & \\
\hline laborfemale | -0.6343 & 0.1409 & 0.9524 & 0.7684 & -0.6608 & 1.0000 \\
\hline
\end{tabular}

Summary statistics: 


\begin{tabular}{|c|c|c|c|c|c|}
\hline Variable & Obs & Mean & Std. Dev. & Min & $\operatorname{Max}$ \\
\hline lnexports & 22 & 3.130141 & 0.256081 & 2.699788 & 3.573793 \\
\hline finalconsum| & 22 & 8.725117 & 2.682059 & 3.836323 & 14.27735 \\
\hline renewableng | & 22 & 25.8839 & 5.176109 & 18.01648 & 32.73963 \\
\hline undernourish | & 22 & 16.92727 & 3.774751 & 11.1 & 24.5 \\
\hline domesticcred | & | 22 & 107.8423 & 14.65172 & 84.49545 & 129.9984 \\
\hline laborfemale| & 22 & 4.35506 & 0.388713 & 43.63855 & 44.709 \\
\hline
\end{tabular}

Interpretation of the results from the model 2. In the above model, we see that final consumption expenditure and renewable energy consumption have a negative relation with exports. We see that undernourishment has a positive relation with exports which might be due to poor labor policies leading to poor work conditions, child labor, etc. Interestingly, we see that in this model too, female labor force participation leads to higher exports. Therefore, both models provide us with an interesting insight into benefits of women empowerment. Greater participation of women in economy leads to greater productivity. Developing countries must invest in women's education, training, and skill development and encourage their employment in various sectors.

\section{Conclusions}

Our study provides distinct and important insights into the Chinese growth experience. We developed two models to understand the impact of innovative policies in China. First model looked at the impact of these policies on GDP per capita growth. The second model discusses their impact on exports. Both models give significant positive effect of participation of female labor force. Hence, women economic empowerment has played an important role in Chinese development in the recent years. Although China needs to improve its governance and eradicate corruption, it has made progress in areas of social and economic development. Hence, developing countries in South Asia and Sub-Saharan Africa can certainly learn from Chinese experience and institutional reforms. However, these countries should incorporate these reforms into their policies after being cognizant of their own local realities and individual trajectories.

\section{References}

Bardhan, P., \& Mookherjee, D. (2006). The rise of local governments: An overview. In P. Bardhan and D. Mookherjee (Eds.), Decentralization and local governance in developing countries: A comparative perspective (pp. 1-52). Cambridge, MA and London: MIT Press.

Byrd, W. A., \& Lin, Q. S. (1990). China's rural industry: Structure, development, and reform. China: Oxford University Press.

Calderón, C., \& Servén, L. (2004). The output cost of Latin America's infrastructure gap. In W. Easterly and L. Servén (Eds.), The limits of stabilization: Infrastructure, public deficits, and growth in Latin America. Washington, D.C.: Stanford University Press.

Dulbecco, P., \& Renard, M.-F. (2003). Permanency and flexibility of institutions: The role of decentralization in Chinese economic reforms. The Review of Austrian Economics, 16(4), 327-346.

Estache, A. (2008). Infrastructure and development: A survey of recent and upcoming issues. In F. Bourguignon and B. Pleskovic (Eds.), Annual World Bank conference on development economics-Global 2007: Rethinking infrastructure for development (pp. 47-82). Washington, D.C.: World Bank. 
Jin, H. H., Qian, Y. Y., \& Weingast, B. R. (2005). Regional decentralization and fiscal incentives: Federalism, Chinese style. Journal of Public Economics, 89(9-10), 1719-1742.

Kozul-Wright, R., \& Rayment, P. (1997). The institutional hiatus in economies in transition and its policy consequences. Cambridge Journal of Economics, 21(5), 641-661.

Li, D. D. (1996). A theory of ambiguous property rights in transition economies: The case of the Chinese non-state sector. Journal of Comparative Economics, 23(1), 1-19.

Lin, J. Y. F., \& Liu, Z. Q. (2000). Fiscal decentralization and economic growth in China. Economic Development and Cultural Change, 49(1), 1-21.

Lin, J. Y. F., \& Nugent, J. B. (1995). Institutions and economic development. In J. Behrman and T. N. Srinivasan (Eds.), Handbook of development economics (Vol. 3). Amsterdam: North-Holland.

McKibbin, W. J., \& Huang, Y. P. (1996). Rapid economic growth in China: Implications for the world economy. Brookings Institution. Retrieved from https://pdfs.semanticscholar.org/f5e9/5479886bd530cce473448b21512c88201fab.pdf

North, D. (1990). Institutions, institutional change and economic performance. Cambridge: Cambridge University Press.

Qian, Y. Y., \& Xu, C. G. (1993). Why China's economic reforms differ: The M-form hierarchy and entry/expansion of the non-state sector. Economics of Transition, 1(2), 135-170.

Sahoo, P., Dash, R. K., \& Nataraj, G. (2010). Infrastructure development and economic growth in China. Retrieved from http://www.ide.go.jp/English/Publish/Download/Dp/pdf/261.pdf

Schellekens, P. (2013). A changing China: Implications for developing countries. Retrieved from http://siteresources.worldbank. org/EXTPREMNET/Resources/EP118.pdf

Wang, J. (2013). The economic impact of special economic zones: Evidence from Chinese municipalities. Journal of Development Economics, 101(C), 133-147.

Weitzman, M. L., \& Xu, C. G. (1994). Chinese township-village enterprises as vaguely defined cooperatives. Journal of Comparative Economics, 18(2), 121-145.

Wong, C. (2006). Can China change development paradigm for the 21st century? Fiscal policy options for Hu Jintao and Wen Jiabao after two decades of muddling through. Retrieved from https://www.swp-berlin.org/fileadmin/contents/products/ arbeitspapiere/2005_03Wng__DevelopmentParadigm_ks.pdf

World Bank. (1994). World development report 1994: Infrastructure for development. New York: Oxford University Press.

World Bank. (2015). The World Bank in China. Retrieved from http://www.worldbank.org/en/country/china/overview

Wu, J. L., \& Huang, S. Q. (2006). The entrepreneurship and institutions: A perspective to interpret China's economic growth in its transformation. Proceedings from William Baumol Special Session on Entrepreneurship, Innovation and Growth at 2006 American Economic Association Meeting. January 8, Boston, USA.

Xu, C. G. (1995). A different transition path: Ownership, performance, and influence of Chinese rural industrial enterprises. New York: Garland Publishing.

Xu, C. G. (2006). Chinese reform and Chinese regional decentralization. Retrieved from http://policydialogue.org/files/events/ $\mathrm{Xu}$ _Chinese_Reform_and_Chinese_Regional_Decentralization.pdf

$\mathrm{Xu}, \mathrm{C}$. G. (2011). The fundamental institutions of China's reforms and development. Journal of Economic Literature, 49(4), 1076-1151.

Yeung, Y.-M., Lee, J., \& Kee, G. (2009). China's special economic zones at 30. Eurasian Geography and Economics, 50(2), 222-240.

Zeng, D. Z. (2011). How do special economic zones and industrial clusters drive China's rapid development? World Bank, Policy Research Working Paper No. 5583.

Zhang, M. (2011). The transition of China's development model. In G20-Perceptions and perspectives for global governance. Retrieved from http://www.kas.de/upload/dokumente/2011/10/G20_E-Book/chapter_6.pdf

Zhu, X. D. (2012). Understanding China's growth: Past, present, and future (digest summary). Journal of Economic Perspectives, 26(4), 103-124. 